\title{
English Trade Disputes Act of 1906
}

"O

NE of the eternal conflicts out of which life is made up is that between the effort of every man to get the most he can for his services, and that of society ... to get his services for the least possible return. Combination on the one side is patent and powerful. Combination on the other is the necessary and desirable counterpart, if the battle is to be carried on in a fair and equal way."

In these words Justice Oliver Wendell Holmes in a notable dissent ${ }^{1}$ touched a fundamental truth concerning the relation of law and society to the battle of trade between capital and labor.

As late as the closing years of the nineteenth century and the dawn of the twentieth, the law of England, based on common-law principles and statutory interpretation, undoubtedly was hampering combinations of workingmen in the competitive economic struggle.

It is true that the Trade Union Act of $1871^{2}$ had removed the criminal stigma attaching to every trade union whose purposes were deemed to be in restraint of trade, and had given to workmen joining registered unions some assurance that the law would reach defalcating treasurers or other officers, and, by the Conspiracy and Protection of Property Act of $1875,{ }^{3}$ the law of criminal conspiracy so far as it touched trade disputes had been abolished.

Furthermore, the Act of 1871 had not removed the unlawful character of trade unions insofar as this illegality was of benefit to them. By this is meant that if the unions were organized to effect purposes deemed in restraint of trade at common law, such as those to fix wages, hours of labor, quantity of work, and to bring about strikes for these ends, the members of the unions could not enforce internal provisions for special benefits-old age and sick pay, for example-on the principle that they were in pari delicto and not entitled to the aid of the law." While such a theory was not complimentary to the unions, it left them free to employ their entire resources in the prosecution of strikes, without legal obligation to set aside funds for the payment of special benefits.

Confronting the laborer at that time, and the organizations

1Vegelahn v. Guntner (1896) 167 Mass. 92, 108, 44 N. E. 1077, 1081, 57 Am. St. Rep. 443, 447, 35 L. R. A. 722, 727.

$234 \& 35$ Vict. c. 31 .

$338 \& 39$ Vict. c. 86.

4 Russell v. Amalgamated Carpenters [1912] A. C. 421, 106 L. T. 433, 56 S. J. 342 . 
which economic forces had impelled him to create, were decisions in four paramount fields of union activity, based on the following three broad legal principles: (1) there existed a common-law immunity from legally unjustifiable interference with a man's trade, business or employment; (2) the establishment of contractual relations between two persons imposed upon the world the duty to refrain from knowing interference therewith; and (3) a combination to violate either the immunity in the first instance or the duty in the second, constituted of itself a legal wrong.

Accordingly the following limitations on trade-union activities were held to flow from the legal principles mentioned:

1-Picketing for purposes other than to obtain or to communicate information was deemed unlawful and might be enjoined. 5

2-Inducing workmen under contract to strike, or inducing employers to discharge workmen under contract by threatening otherwise to strike, with knowledge of said contracts, was deemed unlawful and might be enjoined and damages awarded. ${ }^{6}$

3-Combining to induce workmen to strike resulting in a breaking of their contracts, with knowledge thereof, or, in the absence of contractual relations, combining knowingly to interfere with the common-law right of every man to dispose of his capital or labor as he wills, was deemed unlawful and might be enjoined and damages awarded. ${ }^{7}$

4-Trade unions as such could be sued in their registered names in respect to the acts committed by them, as heretofore outlined, in the course of trade disputes, and trade-union funds reached in satisfaction of judgments against them. ${ }^{8}$

The net practical result of a considerable body of litigation during the years 1893 to 1905 involving the respective rights and duties of capital and labor nuay thus be summed up: effective

5 Lyons and Sons v. Wilkins [1896] 1 Ch. 811; Walters v. Green [1899] 2 Ch. 696.

${ }^{6}$ Lumley v. Gye (1853) 2 El. \& B1. 216, 118 Eng. Rep. Reprint 749 ; Bowen v. Hall (1881) 6 Q. B. D. 333, 44 L. T. 75; Temperton v. Russell [1893] 1 Q. B. 715, 59 L. T. 78; Quinn v. Leathem [1901] A. C. 495, 85 L. T. 289 ; Read v. Friendly Society of Operative Stonemasons [1902] $2 \mathrm{~K}$. B. 732, 16 T. L. R. 20, 87 L. T. 493; Giblan v. National Amalgamated Labourers' Union [1903] 2 K. B. 600,22 T. L. R. 543, 95 L. T. 561 ; South Wales Miners' Federation v. Glamorgan Coal Co. [1905] A. C. 239, 21 T. L. R. 441, 92 L. T. 710 .

7 Temperton v. Russell, Quinn v. Leathem, supra, n. 6.

8 Taff Vale Ry. Co. v. Amalgamated Railway Servants [1901] A. C. 426, 17 T. I. R. 698,85 L. T. 147. 
picketing was denied organized labor; effective use of the strike as a weapon in strengthening the union and in securing advanced working conditions as to wages and hours of labor was rendered uncertain and precarious under the law of civil conspiracy enunciated in Quinn v. Leathem in 1901 and under the earlier doctrine of Lumley v. Gye; activities of trade unions were seriously crippled by the drain on their treasuries in combating civil actions arising out of strikes and in paying damages to employers and discharged non-unionists in respect thereto. (For example, the Taff Vale case is estimated to have cost the union $\{50,000$ ). Moreover, growing fear of the consequences of the law as it then stood and was being enforced undoubtedly prevented the weaker unions from asserting what economic power they might otherwise have wielded, and took away from the stronger organizations many of the benefits they had contemplated from concerted action in the competition of the market.

As if this status of the labor law of England was not sufficiently embarrassing to the workingmen in their efforts toward ameliorating conditions deemed prejudicial to their existence, it appeared that what they were being legally enjoined from doing, in the way of combination and plans for control by union men, was held lawful when done by business men in pursuit of commercial competition.

In 1892 the House of Lords had declared it perfectly proper for a number of shipowners, in order to obtain for themselves a monopoly of the Chinese tea-carrying trade, to combine to underbid all rivals in the matter of freights and offer a rebate of five per cent to all shippers dealing exclusively with them, and to threaten with dismissal their agents who should act for their trade rivals. ${ }^{2}$ Since the means there employed by the defendants to induce third persons not to enter into contracts with plaintiffs consisted in the offers to said third persons of lower prices, money refunds, and threats of taking away business from disobeying agents, the mere existence of an intention to injure plaintiffs in their trade and business was held not to be enough to constitute a legal grievance.

In 1893, however, the Court of Queen's Bench decided that if the means used by union men to induce third persons not to enter into contracts with a builder against whom a strike was pend-

${ }^{9}$ Mogul Steamship Co. v. McGregor [1892] A. C. 25, 66 L. T. 1, 61 L. J. Q. B. 295. 
ing, were threats of taking away employees from said third persons, there arose an actionable wrong. ${ }^{10}$ Lord Justice Lopes declared: "The result of the authorities appears to me to be that a combination by two or more persons to induce others not to deal with a particular individual, or enter into contracts with him, if done with the intention of injuring him, is an actionable wrong if damage results to him therefrom." And for this proposition of law, the Mogul Steamship case was cited among the precedents. Certainly in the Mogul case there was combination by shipowners to induce others not to deal with plaintiffs with intention to injure them. Yet no unlawful act was there held committed. That was considered a case of legitimate trade competition, while the case of Temperton v. Russell was thought to be otherwise. In view of the subsequent declaration of Lord Shand in Allen v. Flood ${ }^{11}$ that shipwrights who knowingly induce their employer not to enter into contracts with ironworkers "for the job" are violating no legal right of the latter since "competition in labour . . . is in all essentials analogous to competition in trade ... and the same principles must apply," and in view of the expressed inability of no less able a jurist than Justice Holmes to reconcile Temperton v. Russell with the Mogul case, certainly the laborer was not entirely at fault in failing to perceive the nicety of legal distinction between the two cases.

After Allen v. Flood, the House of Lords approved Temperton v. Russell in Quinn v. Leathem, holding that union officials, in combining to secure the discharge of plaintiff's non-union employees by threatening plaintiff's customers with a strike in their establishments, unless they refrained from dealing with plaintiff, were using unlawful means to accomplish their ends. Whether this case may truly be reconciled with Allen v. Flood and the Mogul case admits of great doubt.

Following South Wales Miners' Federation v. Glamorgan Coal Company in $1905,{ }^{12}$ where the employers recovered damages from a union which ordered a "stop-day" obeyed by over 100,000 men who thereby broke their contracts for that day, although it was expressly found that the action of the Federation was inspired by an honest desire to forward the interest of the workmen and was not in any sense prompted by a wish to injure the company,

10 Temperton v. Russell, supra, n. 6.

11 [1898] A. C. 1, 164, 77 L. T. 717, 67 L. J. Q. B. 119.

12 Supra, n. 6. 
between whom and the men there was no quarrel or ill-will, organized labor of Britain took its case to Parliament, seeking immunity during trade disputes from what they felt were oppressive consequences of the common-law principles enunciated in labor cases.

Marking a new epoch in labor legislation, Parliament, on December 21, 1906, wrote on the statute books the Trade Disputes Act of $1906^{13}$ aiming to accomplish the following results:

1-Peaceful picketing was to be lawful where carried on by one or more persons on their own behalf or on behalf of a trade union in contemplation or furtherance of a trade dispute, not only to obtain or communicate information, but also to persuade any person to work or abstain from working.

2-Inducing workmen under contract to strike, or inducing employers to discharge workmen under contract, or in the absence of contractual relations interfering with the trade, business or employment of some other person, or with the right of some other person to dispose of his capital or his labor as he wills, in contemplation or furtherance of a trade dispute, was not to be unlawful.

3-Combining to accomplish any of the purposes already noted in (1) and (2), if done in contemplation or furtherance of a trade dispute, was not to be unlawful, unless the act if done without such agreement or combination were actionable.

4-Trade unions as such were not to be suable in respect to any tortious act alleged to have been committed by them or on their behalf. This immunity was not to be limited to trade disputes, but was to be full and complete.

Protection to trade unions and to workingmen, and to employers' associations and employers as provided in the statute, being confined to acts done in contemplation or furtherance of a trade dispute, the law defined a trade dispute as "any dispute between employers and workmen, which is connected with the employment or non-employment or the terms of the employment, or with the conditions of labor, of any person, and the expression 'workmen' means all persons employed in trade or industry, whether or not in the employment of the employer with whom a trade dispute arises."

Thus half a century after Lumley v. Gye was decided and five short years after the law of civil conspiracy had been developed in Quinn v. Leathem, organized labor seemingly won its appeal

136 Edw. 7, ch. 47. 
from the decisions of the House of Lords before the tribunal of last and final resort-public opinion. Undoubtedly it was the sense of Parliament that the law of Lumley v. Gye, while socially sound in cases of private competitive conflict between individuals, was not socially desirable when extended to the competition between labor and capital involving large labor organizations constituting a major portion of the population, and interpreted to embarrass workmen in their attempts to improve conditions.

Fifteen years have passed since the adoption of the Trade Disputes Act of 1906. An attempt to limit the apparently unlimited immunity of trade unions, in respect to alleged tortious acts committed by them, to cases involving trade disputes only failed in Vacher and Sons, Limited v. London Society of Compositors, ${ }^{14}$ the House of Lords declining to insert in section four the words "in contemplation or furtherance of a trade dispute" where they had not been inserted by Parliament.

But it has not been section four, but sections three and five with which the courts have been principally concerned. Since individuals invoking the protection of the Act are confined to cases of trade disputes only, it has been necessary for the courts to interpret the statutory definition of a trade dispute. It has been contended that section three lixnits the immunity from commonlaw principles to cases where the only ground of complaint is inducing a breach of contract or interfering with common-law trade and business rights, and that in every instance where another ground of complaint is alleged, such as inducing the breach by illegal means (threats, violence, and the like), the Act may not apply. For this reason plaintiffs since 1906 have contended for a marked limitation of the statutory definition of "trade dispute" and have sought to make out a case of "threats" where defendants in large numbers brought about the breaking of the contracts.

In this connection the distinction between Allen v. Flood and Quinn v. Leathem is argued to be of paramount importance. If defendants merely give notice to the employer, as in the former case, that the employees are discontented and are planning to strike, the means here used in accomplishing the result sought, the discharge of the objectionable men, are considered peaceful and lawful. But if, as in the latter case, the defendants coerce or threaten plaintiff into compliance with their demands, as by threatening the plaintiff's customers with a strike in their establish- 
ments unless they refrain from dealing with plaintiff, the means here are considered minatory and unlawful, and the Act, it is argued, affords no shelter.

As yet the House of Lords has not been asked or required directly and authoritatively to meet these issues. In Conway v. Wade ${ }^{15}$ the jury negatived the existence of a trade dispute where defendant, in order to compel plaintiff to pay a seven-year-old union fine, but acting without authority from his union and in violation of its rules, procured the discharge of plaintiff by threatening otherwise to call out all union men. Lord Collins stated that the House was not called upon to put a construction on the recent Act since no trade dispute had been found. Lord Chancellor Loreburn, by way of dictum, declared that if there be threats or violence, section three gives no protection, for then there is some other ground of action besides the ground that a breach of contract has been induced. In Larkin v. Long ${ }^{16}$ the House of Lords held that the Act did not apply to a dispute between an employer and an employer, and hence that defendant stevedore, an employer of dock laborers, was accordingly liable for inducing plaintiff's dock workers to leave him because plaintiff would not join the employers' association of which defendant was a member.

In the lower courts some half-dozen labor cases have been decided. During 1912 and 1913 the Trade Disputes Act as a defence was invoked three times, in each case with success.

Gaskell v. Lancashire Miners ${ }^{17}$ was the first of these. There defendants verbally informed the employers by their manager that if plaintiffs, non-union men, were retained, the executive committee of defendant federation had decided to call out the men. This information was repeated to the manager, whereupon plaintiffs were discharged. Cozens-Hardy, Master of the Rolls, held that there was a trade dispute on the question whether non-union men should be employed at the colliery. The dispute here was connected with the employment or non-employment of non-unionists.

In Dallimore v. Williams ${ }^{18}$ officials of the Amalgamated Musicians' Union induced plaintiff's performers to break their contracts calling for a Sunday pay schedule below that of the union, with the result that plaintiff, in order to retain his men, was required to pay more than the amount stipulated in the original contract.

15 [1909] A. C. 506, 25 T. L. R. 779, 101 L. T. 248, 53 S. J. 754.

16 [1915] A. C. 814,31 T. L. R. 405, 113 L. T. 337, 59 S. J. 445.

17 (1912) 28 T. L. R. 518, 56 S. J. 719.

18 (1912) 29 T. L. R. 67; (1914) 30 T. L. R. 432. 
The Court of Appeal, reversing Mr. Justice Ridley, held that there was a trade dispute. On appeal after a second trial judgment for defendants was entered on the verdict. Here was a dispute connected with the terms of the employment.

In Santen v. Busnach ${ }^{19}$ the employer testified that defendant, a woman cigarmaker in his employ, in an interview with him said that if plaintiff, also a woman cigarmaker not a member of defendant's union, remained in the employ, she and others would not stay, whereupon he discharged plaintiff. Here there was a dispute connected with the employment or non-employment of a nonunion laborer.

In all these pre-war cases a trade dispute was deemed existing, and the Court of Appeal in each instance could find no evidence of threats to take the case out of the language of section three of the Act. Labor, it seemed, had secured a decision-proof statute protecting its activities and putting to rest the doctrines of Lumley v. Gye, Temperton v. Russell, and Quinn v. Leathem, so far as they might affect acts arising out of trade disputes.

Out of the clear sky in July, 1919, however, came the decision against defendants, union officials, in Valentine v. Hyde, ${ }^{20}$ based expressly on the authority of the three cases just mentioned. It appeared that the Bridgwater Collieries employed 6,000 men, of whom all but eight, including plaintiff, belonged to one of four local unions. Defendants, in pursuance of a resolution by their union, interviewed the manager of the collieries, and the latter agreed that all the men should belong to one of the four unions. No threat was made, no warnings given, or downing of tools mentioned, according to the uncontradicted testimony of defendants, and no threatening language was made use of, according to the opinion of Mr. Justice Astbury. Plaintiff refused to join defendants' union on the ground that his own trade society forbade such action under penalty of depriving him of the benefits accruing from thirty-seven years' membership therein. Plaintiff was working under union conditions but, on refusal to join the union, he was discharged.

Invoking a theory that to receive the protection of the Trade Disputes Act of 1906 the dispute in question must be of some substantial consequence to the defendant so far as the union's control was concerned, and that since in the case the unions were in

19 (1913) 29 T. L. R. 214, 57 S. J. 226.

20 [1919] 2 Ch. 129, 35 T. L. R. 301, 120 L. T. 653,63 S. J. 390. 
absolute control and the non-joining of plaintiff was of no material difference to the union (although by express resolution they declared it was), Mr. Justice Astbury held that the dispute was not a "trade dispute" within the meaning of the Act; and secondly, that even if a trade dispute did exist, since the employer was aware of the power of the unions arising from their preponderant numbers, the information given him by defendant under the circumstances amounted to moral intimidation, and, following Lord Loreburn's dictum in Conway v. Wade, and the doctrine of civil conspiracy in Temperton. v. Russell and Quinn v. Leathem, section three of the Act was held not to apply. Defendants were held liable in damages and were enjoined from continuing the acts complained of.

The same learned justice applied these same principles and came to the same decision in the latter case of White v. Riley ${ }^{21}$ wherein defendant presented to the employer the following notice: "We hereby give notice that we shall cease work on Friday next unless E. White joins our society or leaves your employment. Signed on behalf of the shop. W. Riley."

Regardless of the apparent hardship on plaintiff resulting from a contrary decision in Valentine v. Hyde, it is submitted that the first of the two theories relied upon by the learned justice finds no support in the language of the Act, and that the second overlooks the first section thereof.

A trade dispute as defined in section five uses the all-inclusive word "any" dispute between employer and workmen, or between workmen and workmen, which is connected with the employment or non-employment, or the terms of employment, or with the conditions of labor, of any person. The dispute in Valentine v. Hyde, which had been considered of sufficient gravity to occasion a resolution by defendants' union, seems clearly to be one connected with the employment or non-employment of plaintiff. The Act does not state in section five that the dispute must be of some material or substantial consequence to the defendant employers or workmen, nor is there any language in any of the other sections indicating that such was the intention of Parliament when the statute was enacted. The learned justice, it must be apparent, supplemented the legislative definition of a trade dispute by adding thereto a condition or proviso that the dispute must be of some consequence to the defendants.

21 [1921] 1 Ch. 1, 36 T. L. R. 849, 64 S. J. 725. 
Insofar as it was further held that the mere presence of numbers of workmen, known to the employer to be supporting or authorizing the demands contained in the notice or warning of contemplated strike in the event of the employer's non-compliance therewith, colors an otherwise innocuous act, it is submitted that section one of the Trade Disputes Act was inserted to prevent the very application of such a doctrine. The principle thus enunciated certainly was considered by organized labor to be the objectionable feature of Quinn v. Leathem. The first section of the Act states "An act done in pursuance of an agreement or combination by two or more persons shall, if done in contemplation or furtherance of a trade dispute, not be actionable unless the act done without any such agreement or combination would be actionable." If Hyde had interviewed the employer as a messenger. it seems according to Mr. Justice Astbury himself, the case would have been a second Allen v. Flood. Granted that premise, it would seem logically to follow that because the information was given in pursuance of an agreement among the members of the union, the first section of the Trade Disputes Act prevents the doctrine of civil conspiracy from applying under the given set of facts. Again, it is submitted that the learned justice overlooked the first section of the Act, and indeed no reference thereto was made. Valentine v. Hyde, it is contended, cannot be sustained.

Four subsequent decisions would seem to bear out this contention. In Hodges $\mathrm{v}$. Webb, ${ }^{22}$ defendant, the secretary of the Electrical Trades Union, not only gave the employer notice that the men would strike if plaintiff electrician was retained, but the strike was actually called and the men walked out. Plaintiff was thereupon discharged. "An authorized official of a trade union cannot be sued merely for inducing members of his union to cease work in support of what was believed to be in the interest of the union," Justice Peterson declared, adding "I respectfully adopt the view of Lord Watson in Allen v. Flood that an employer cannot properly [legally] be said to be coerced if, having two alternatives presented to him, he follows that course which he considers himself conducive to his own interests."

The second decision was Wolstenholme v. Ariss ${ }^{23}$ where plaintiff's employer was notified by defendant, the secretary of the Amalgamated Musicians' Union, of a resolution adopted by the

22 [1920] 2 Ch. 70, 36 T. L. R. 311.

23 [1920] 2 Ch. 403,123 I. T. 741, 89 I. J. Ch. 395. 
union that plaintiff had been expelled and that any member employed with him would be treated as a non-member. The employer, who was also a member of the union, discharged plaintiff upon two weeks' notice. Justice Eve declined to hold defendant liable on the ground that there was no breach of contract, nor were threatening or coercive means used.

The third decision was in the Court of Appeal, ${ }^{24}$ reversing Justice Astbury in White v. Riley. Lord Sterndale, Master of the Rolls, declared that he preferred the reasoning of Justice Peterson in Hodges v. Webb to that of Justice Astbury in Valentine v. Hyde, and Lord Justice Warrington said he could not appreciate the reasoning of the learned justice in the latter case.

If the whole efficacy of section three of the Trade Disputes Act is to depend upon the metaphysical distinction between coercion and warning, as Justice Astbury holds, Justice Peterson's statement in reference thereto is apposite: "Free will has been much discussed in the region of metaphysics, and lawyers might be content that the discussion should not be extended to the realm of law."

In the fourth case of Wake and DeFreville, Limited v. Motor Trade Association, ${ }^{25}$ the Court of Appeal re-examined and reanalyzed all the leading English cases on the subject, and concluded that the defendant union was acting within its legitimate interests in publishing plaintiffs' name on its stop list spread broadcast in the trade, giving notice that plaintiffs sold cars at other than fixed prices. What effect such publication would have is readily ascertained from reading defendant's by-laws providing that no member of its association should have any trade relations with persons named in such stop list. The court approves Hodges v. Webb, and Lord Justice Scrutton supports Justice Holmes' dissent in Vegelahn v. Guntner, ${ }^{26}$ terming it an admirable judgment.

Thus stands the law of England, with the ultimate fate of the Trade Disputes Act depending upon the future decision of the House of Lords.

In passing it may be noted that Parliament has further singled out trade disputes and the legal problems arising from their nature from the field of ordinary legal relations between private subjects, in the adoption of the Industrial Courts Act on November 20,

24 [1921] 1 Ch. 1, 89 L. J. Ch. 628, 36 T. L. R. 849.

25 (1921) 37 T. L. R. 213, 125 L. T. 265, 65 S. J. 239.

26 Supra, n. 1. 
1919.27 Any trade dispute, it is provided, existing or apprehended, may be reported to the Minister of Labor who, upon the consent of both parties, may refer the matter for settlement to the Industrial Court, which is created by law, or to arbitration. A Court of Inquiry also is constituted which may inquire into the facts of trade disputes, and publicly present its findings. While under the statute no binding force is given to the decisions of the courts thus established, this late piece of legislation is undoubtedly significant in showing further recognition by Parliament of the peculiar legal status of trade unions, and in thus attempting to provide for the adjustment of differences arising in the economic market on other than strictly extended common-law principles.

$$
\text { J. J. Posner }
$$

San Francisco, California. 